\title{
DETERMINATION OF POROSITY IN FLUIDIZED - BED CARBURIZED P/M COMPACTS USING AN IMAGE SOFTWARE ANALYSIS
}

\author{
Mihaela MARIN, Florin-Bogdan MARIN \\ "Dunarea de Jos" University of Galati, Romania \\ e-mail: mihaela.marin@ugal.ro
}

\begin{abstract}
The aim of this research was to study the porosity in carburizing in fluidizedbed on sintered alloys produced by powder metallurgy route using an image analysis software and to compare the obtained results with the conventional method for porosity measurements. Porosity is a measure of the void fraction in a material. The total porosity is defined by the ratio of the volume of void space to the total bulk volume of the material, expressed as a percentage. Development of digital images and computer software lead to a new and suitable method to determine the porosity of powder metallurgy materials.
\end{abstract}

KEYWORDS: powder metallurgy, sintering, fluidized bed carburizing, porosity, image software

\section{Introduction}

Powder metallurgy $(\mathrm{P} / \mathrm{M})$ is an important alternative technology of lower cost process. The main problem of $\mathrm{P} / \mathrm{M}$ products is the presence of pores due to the fact the pores act as potential crack initiation sites and can also guide and propagate cracks through the material. The conventional P/M processing can produce iron-based $\mathrm{P} / \mathrm{M}$ parts with a density less than $7.1 \mathrm{~g} / \mathrm{cm}^{3}$, so their mechanical properties are considerably less than their full density part obtained by classic metallurgy [1-3]. The properties of sintered $\mathrm{P} / \mathrm{M}$ alloys can be improved by adding alloying elements [4-7]. The most commons alloying elements added in powder form are: copper, nickel, molybdenum, manganese and phosphorus. $\mathrm{Cu}$ increase the toughness and density by filling the pores due to melting during the sintering process (copper melts at $1083{ }^{\circ} \mathrm{C}$ ) [8-11]. Nickel (Ni) increases the sintered density due to the formation of the Ni-rich areas during sintering in solid state which have a positive influence on hardness and strength by providing a local ductility [12, 13]. Molybdenum (Mo) has a good response in hardenability [14].

Another way to improve the properties of these alloys is by applying heat, thermochemical or mechanical treatments [15-22]. Fluidized bed carburizing is a thermochemical treatment that provides high heat and mass transfer.

The goal of this paper is to study the porosity in some fluidized bed carburizing sintered P/M materials by applying an image software tool and to compare the obtained results with the results obtained by the conventional method.

\section{Experimental procedure}

The specimens studied in this paper are represented by atomized iron powder and pre-alloyed iron base powder. The chemical composition of the powders, pure iron and iron-based pre-alloyed powder with $\mathrm{Cu}, \mathrm{Ni}$ and $\mathrm{Mo}$ is presented in Table 1 . The raw samples were mixed with $1 \%$ zinc stearate. The green compacts, obtained at $600 \mathrm{MPa}$ pressure using a single die action, were sintered in a laboratory furnace at $1150{ }^{\circ} \mathrm{C}$ for 60 minutes. The obtained disc specimens have the dimensions of $\phi 8 \times 6 \mathrm{~mm}$. After cooling to room temperature, the samples were subjected to fluidized bed carburizing treatment at $900{ }^{\circ} \mathrm{C}$ during 60 minutes. 
Table 1. Chemical composition of analysed powders

\begin{tabular}{|c|c|c|c|c|}
\hline Powder type & $\mathbf{C u}$ & Mo & Ni & C \\
\hline $\mathrm{P}_{1}$ & 0.096 & 0.008 & 0.046 & $<0.01$ \\
\hline $\mathrm{P}_{2}$ & 1.50 & 0.50 & 1.75 & $<0.01$ \\
\hline
\end{tabular}

\section{Results and discussions}

\subsection{Density results}

The green, sintered and carburized in fluidized bed densities of the specimens were determined by using geometrical method, weight and dimensional measurements. The measurements result of the density in green state, sintered and carburized in fluidized bed, measured from by conventional technique are presented in Fig. 1.

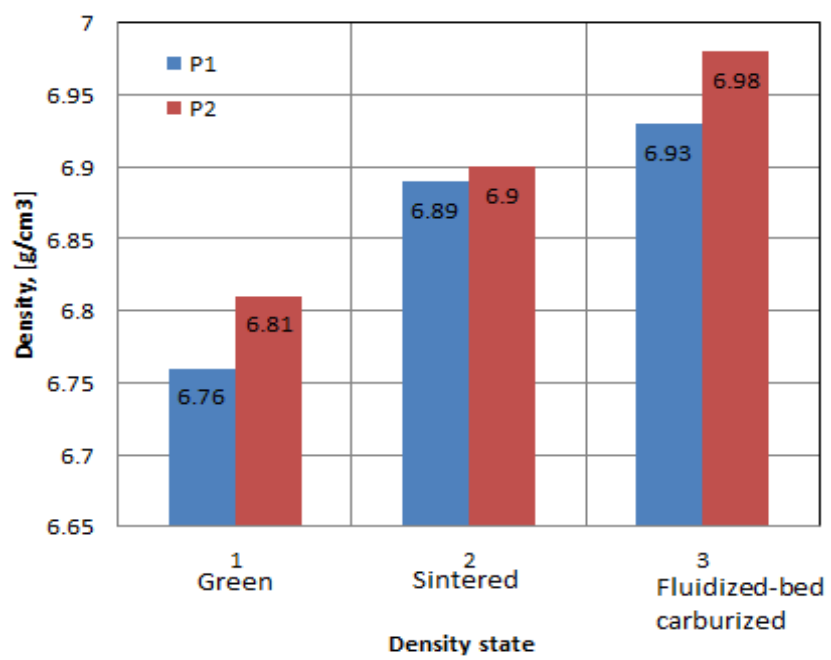

Fig. 1. Green density, sintered and carburized in fluidized bed density for analysed specimens

\subsection{Microstructure analysis}

The microstructures of fluidized bed carburized samples were observed by optical microscopy (Olympus BX 51M) at $100 \mathrm{X}$ are presented in Figure 2. Examination of Figure 2 shows that the optical micrographs of the carburized in fluidized bed specimen P1 has the pores larges and irregulars than pores in the sample with the highest density, P2.

\subsection{Porosity measurements}

In Table 2 are presented the porosity measurements of $\mathrm{P} / \mathrm{M}$ products calculated using the conventional method from density technique. Another method for porosity measurements was using an image processing software tool, Image J. Image J [23] is a free and useful image analysis software tool to analyse using filters, adjustments and Threshold binary function in detection the porosity. In [24-26], Image $\mathrm{J}$ was applied to study porosity in sintered $\mathrm{P} / \mathrm{M}$ specimens. The images acquisition was carried out for non-etched samples using a digital camera coupled to optical microscope. By extrapolation the areas with pores using the function of Thresholding, the program generates the separate image only with porosity and can calculate it in percent. The porosity measurements result of carburized in fluidized bed samples using Image $\mathbf{J}$ software are presented in Table 2 and Fig. 3.

Table 2. The porosity of analysed alloys in carburized in fluidized bed state

\begin{tabular}{|c|c|c|}
\hline $\begin{array}{c}\text { Powder } \\
\text { type }\end{array}$ & $\begin{array}{c}\text { Porosity from } \\
\text { conventional method } \\
(\boldsymbol{\%})\end{array}$ & $\begin{array}{c}\text { Porosity from image } \\
\text { analysis } \\
(\boldsymbol{\%})\end{array}$ \\
\hline $\mathrm{P}_{1}$ & 9.85 & 11.73 \\
\hline $\mathrm{P}_{2}$ & 8.91 & 10.44 \\
\hline
\end{tabular}


The measurements of porosity resulted from density technique are ranging from $8.91 \%$ to $9.85 \%$. The measurements of porosity resulted by using the Image J software are ranging from $10.44 \%$ for 6.93 $\mathrm{g} / \mathrm{cm}^{3}$ to $11.73 \%$ for $6.98 \mathrm{~g} / \mathrm{cm}^{3}$. A correlation between higher density and a decreasing in porosity was established. The sample P2 had a lower porosity. Also, the Image $\mathbf{J}$ software can generate a 3D image of the surface for the carburized in fluidized bed samples presented in Fig. 4.
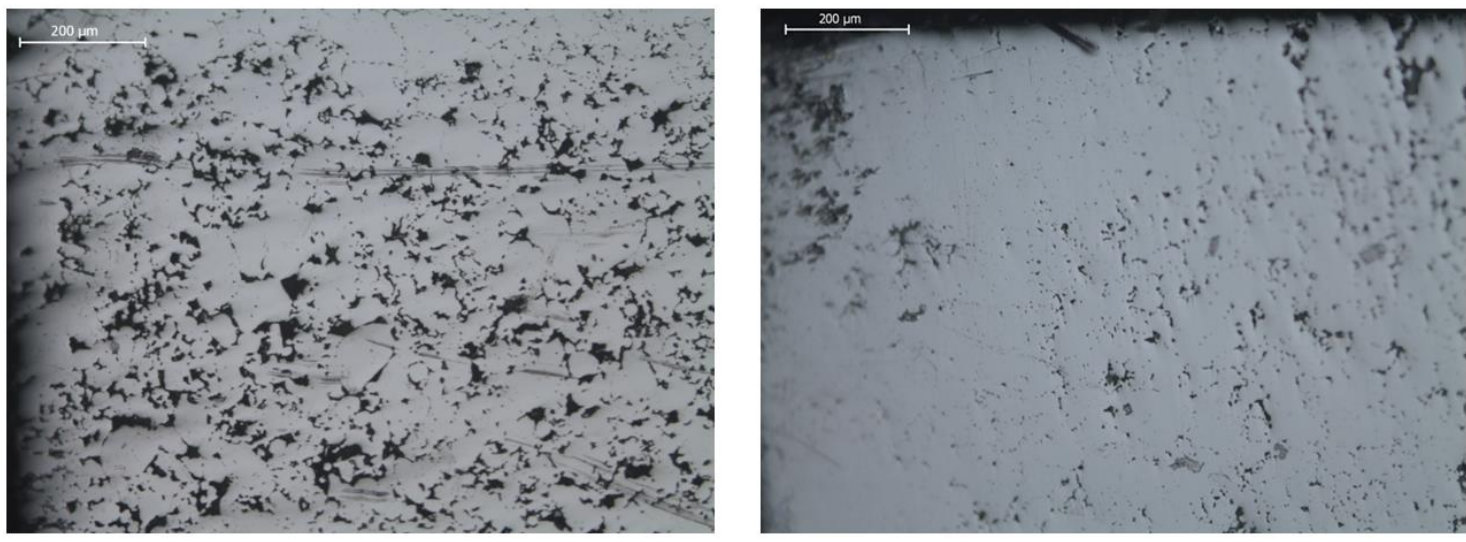

Fig. 2. Micrographs of the non-etched carburized in fluidized bed samples a) $P 1$; b) P2
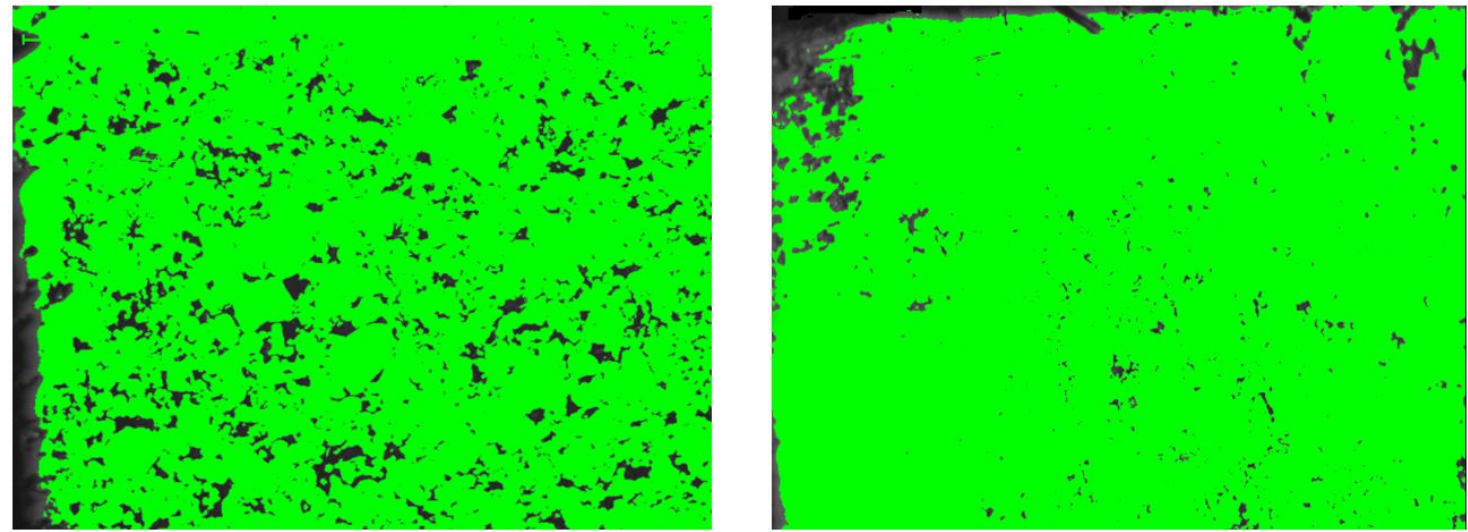

Fig. 3. Processed images by using the image software for porosity measurements of carburized in fluidized bed samples: a) $P 1$; b) $P 2$
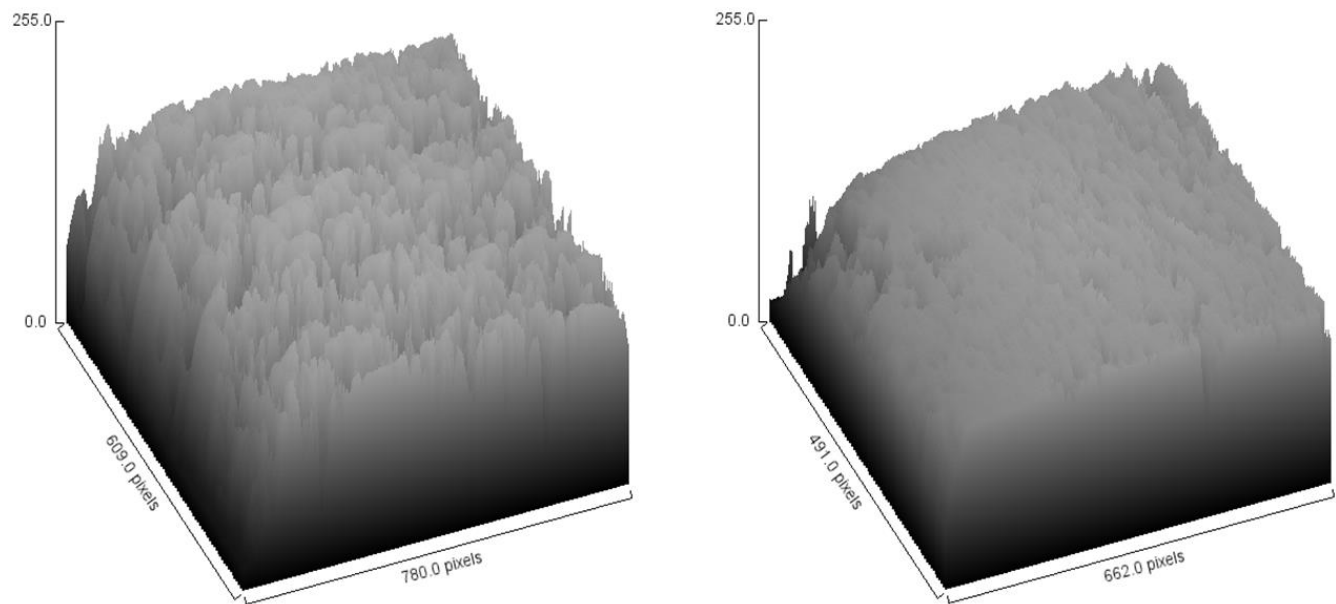

Fig. 4. 3D image of the surface for the carburized in fluidized bed samples, obtained using image software: a) $P 1$; b) $P 2$ 


\section{Conclusions}

The measurements of porosity in fluidized bed carburized state of analysed samples, using image analysis software - Image $\mathbf{J}$ was correlated to the density results obtained by geometrical method.

A correlation between higher density and a decreasing in porosity was established. The sample P2 had a lower porosity.

A correlation between the experimental and software data analysis was established, the porosity measured from image analysis was higher than from density technique due to the fact that only open porosity is considered in the image analysis technique, so the closed porosity is not accounted in the image analysis. An increase in the sintered and carburizing in fluidized bed density of the samples was correlated with a lower porosity and smaller pore size.

\section{References}

[1]. Narasimhan K. S., Sintering of powder mixtures and the growth of ferrous powder metallurgy, Materials Chemistry and Physics, vol. 67, p. 56-65, 2001.

[2]. Jang G. B., Hur M. D., Kang S. S., A study on the development of a substitution process by powder metallurgy in automobile parts, J Mater Process Technol, p. 110-115, 2000.

[3]. Hamiuddin M., Correlation between mechanical properties and porosity of sintered iron and steels-a review, Powder Metall. Int. 18, p. 73-76, 1986

[4]. Wu M. W., Tsao L. C., Shu G. J., Lin B. H., The effects of alloying elements and microstructure on the impact toughness of powder metal steels, Materials Science and Engineering: A 538, p. 135-144, DOI: 10.1016/j.msea.2011.12.113, 2011.

[5]. Maheswari N., Ghosh Chowdhury S., Hari Kumar K. C. Sankaran S., Influence of alloying elements on the microstructure evolution and mechanical properties in quenched and partitioned steels, Materials Science and Engineering: A, 600, p. 12-20, 2014.

[6]. Wu M. W., Tsao L. C., Shu G. J., Lin B. H., The effects of alloying elements and microstructure on the impact toughness of powder metal steels, Materials Science and Engineering: vol. A 538, p. 135-144, 2012.

[7]. Trivedi S., Mehta Y., Chandra K., Mishra P. S., Effect of carbon on the mechanical properties of powder-processed $\mathrm{Fe}-0.45$ wt\% $P$ alloys, Indian Academy of Sciences, vol. 35, part 4, p. 481492, 2010.

[8]. Angel W. D., Tellez L., Alcala J. F., Martinez E., Cedeno V. F., Effect of copper on the mechanical properties of alloys formed by powder metallurgy, Materials and Design, vol. 58, p. 12-18, 2014.

[9]. Marucci M. L., Hanejko F. G., Effect of copper alloy addition method on the dimensional response of sintered $\mathrm{Fe}-\mathrm{Cu}-\mathrm{C}$ steels, Advances in Powder Metallurgy and Particulate Materials, MPIF, p. 1-11, 2010
[10]. Dong Y., Jun L., Wen J., Jie S., Kunyu Z., Effect of $C u$ addition on microstructure and mechanical properties of $15 \% \mathrm{Cr}$ super martensitic stainless steel, Mater Des, vol. 41, p. 16-22, 2012.

[11]. Takaki S., Fujioka M., Aihara S., Nagataki Y., Yamashita Y., Sano N., Adachi Y., Nomura M., Yaguchi K., Effect of Copper on Tensile Properties and Grain-Refinement of Steel and its Relation to Precipitation Behavior, Mater Trans, vol. 45, p. 2239-2244, 2005.

[12]. Bernier F., Plamondon P., Bailon J. P., Esperance G. L., Microstructural characterisation of nickel rich areas and their influence on endurance limit of sintered steel, Powder Metallurgy, vol. 54, issue 5, p. 559-565, 2011.

[13]. Sulowski M., Structure and mechanical properties of sintered Ni free structural parts, Powder Metallurgy, vol. 53, no. 2, p. 125$140,2010$.

[14]. Sanjay S. R., Milind M. S., Vikram V. D., Effect of molybdenum addition on the mechanical properties of sinter-forged $\mathrm{Fe} \mathrm{Cu} \mathrm{C} \mathrm{alloys,} \mathrm{Journal} \mathrm{of} \mathrm{Alloys} \mathrm{and} \mathrm{Compounds} \mathrm{649,} \mathrm{p.} \mathrm{988-}$ 995, 2015.

[15]. Mansoorzadeh S., Ashrafizadeh F., The effect of thermochemical treatments on case properties and impact behaviour of Astaloy CrM, Surface and Coatings Technology, vol. 192, issue 2-3, p. 231-238, 2005.

[16]. Kazior J., Janczur C., Pieczonka T., Ploszczak J., Thermochemical treatment of $\mathrm{Fe}-\mathrm{Cr}-\mathrm{Mo}$ alloys, Surface and Coatings Technology, vol. 151-152, p. 333-337, 2002.

[17]. Krauss G., Principles of Heat Treatment of Steels, American Society for Metals, ASM International, 2003.

[18]. Radomyselsk I. D., Zhornyak A. F., Andreeva N. V., Negoda G. P., The pack carburizing of dense parts from iron powder, Powder metallurgy and metal ceramics, vol. 3, p. 204-211, 1964.

[19]. Askaria M., Khorsand H., Mohamad Aghamiri, Influence of case hardening on wear resistance of a sintered low alloy steel, Journal of Alloys and Compounds, vol. 509, issue 24, p. 68006805,2011

[20]. Krauss G., Microstructure residual stress and fatigue of carburized steels, Proceedings of the Quenching and Carburizing, The Institute of Materials, p. 205-225, 1991.

[21]. Georgiev J., Pieczonka T., Stoytchev M., Teodosiev D., Wear resistance improvement of sintered structural parts by $\mathrm{C} 7 \mathrm{H7}$ surface carburizing, Surface and Coatings Technology, vol. 180181, p. 90-96. 2004

[22]. Sulowski M., How processing variables influence mechanical properties of PM Mn steels?, Powder Metallurgy Progress, vol. 7, no. 2, 2007.

[23]. ***, Image J software- https://imagej.nih.gov/ij/.

[24]. Marin M., Potecaşu F., Potecaşu O., Marin F. B., Image Analysis Software for Porosity Measurements in Some Powder Metallurgy Alloys, Advanced Materials Research, vol. 1143, p. 103-107, Trans Tech Publications, Ltd., 2017.

[25]. Dobrzanski L., Musztyfaga M., Actis Grande M., Rosso M., Computer aided determination of porosity in sintered steels, Archives of Materials Science and Engineering, vol. 38, no. 2., p. 103-11, 2009.

[26]. Dobrzanski L. A., Musztyfaga-Staszuk M., Luckos A., The comparison of computer methods for porosity evaluation in sintered constructional steels, Journal of Achievements in Materials and Manufacturing Engineering, vol. 61, no. 2, p. 395402, 2013. 